\title{
위눈꺼풀 지방종
}

\section{Eyelid Lipoma}

\author{
이상묵 · 이민정 \\ Sang Muk Lee, MD, Min Joung Lee, MD \\ 한림대학교 의과대학 한림대학교 성심병원 안과학교실 \\ Department of Ophthalmology, Hallym University Sacred Heart Hospital, Hallym University College of Medicine, Anyang, Korea
}

\begin{abstract}
Purpose: To report a rare case of eyelid lipoma.
Case summary: A 41-year-old female presented with a palpable mass in her left upper eyelid. Diffuse hard mass was palpable at preaponeurotic fat layer of left upper eyelid, and there was no inflammatory sign. Under local anesthesia, a left upper eyelid mass partial excision was performed and a biopsy specimen was collected. The mass was yellower and harder than surrounding normal eyelid fat. A lipoma was diagnosed based on histopathological findings such as proliferation of mature adipocytes.

Conclusions: Lipoma is a benign tumor commonly found around trunk and limbs, but rarely occurs at eyelid. Eyelid lipoma should be considered as a differential diagnosis of diffuse mass at eyelid fat layer. Diagnosis and treatment can be achieved by partial excision and histopathological examination.
\end{abstract}

J Korean Ophthalmol Soc 2021;62(7):989-992

Keywords: Eyelid, Eyelid tumor, Lipoma

지방종은 성숙 지방세포로 구성된 양성종양으로 정의된 다. 몸 어느 부위에서나 발생할 수 있고 보통 몸통, 허벅지, 팔다리에 많이 발견된다. ${ }^{1}$ 연부조직 기원 양성종양 중에서 가장 흔한 종양이지만, 눈꺼풀에 발생하는 경우는 매우 드 물다. 저자들은 눈꺼풀에 발생한 지방종 1 예를 경험하였기 에 이를 문헌 고찰과 함께 보고하려 한다.

\section{증례보고}

41세 여자 환자가 좌측 위눈꺼풀의 만져지는 종괴를 주

- Received: 2020. 10. 12.

- Revised: 2021. 1. 2.

- Accepted: 2021. 6. 20.

- Address reprint requests to Min Joung Lee, MD

Department of Ophthalmology, Hallym University Sacred Heart

Hospital, \#22 Gwanpyeong-ro 170beon-gil, Dongan-gu,

Anyang 14068, Korea

Tel: 82-31-380-3834, Fax: 82-31-380-3833

E-mail: minjounglee77@gmail.com

* Conflicts of Interest: The authors have no conflicts to disclose.
소로 내원하였다. 2 달 전부터 좌측 위눈꺼풀에 종괴가 만져 져 인근 안과 방문하여 항생제를 1주간 복용하였으나 호전 되지 않아 본원 내원하였다. 안과적 과거력으로 수년 전에 양안 쌍꺼풀수술을 받은 기왕력과 5개월 전 양안 굴절교정 수술을 받은 병력이 있었으며, 다른 전신 기저질환은 없었 다. 안면 필러주입술 혹은 안면 지방주입술의 병력은 부인 하였다.

처음 내원하였을 때 나안 시력 우안 1.0 , 좌안 1.0 이었으 며, 비접촉 안압계로 측정한 안압은 우안 $11 \mathrm{mmHg}$, 좌안 $13 \mathrm{mmHg}$ 였다. 이학적 검사상 좌측 위눈꺼풀 널힘줄안와 지방으로 추정되는 부위에 연조직 느낌으로 덩어리진 종괴 가 만져졌다(Fig. 1A). 눈꺼풀각막반사거리 1 는 우안 +5 , 좌 안 +4 였으며, 눈꺼풀 내림지체는 관찰되지 않았고, 발적, 부종, 압통 등 염증성 변화를 의심할 만한 소견은 없었다. 조영증강안와 전산화단층촬영(computed tomography, CT) 검사에서는 좌측 눈꺼풀의 안와사이막 뒤쪽으로 미만성의 조영증강이 되지 않는 저음영의 종괴가 관찰되었으며, 이 외에는 특이 소견이 관찰되지 않았다(Fig. 1B). 항체검사를 
포함한 갑상샘기능검사는 정상이었다.

진단적 목적과 함께 미용적 개선을 위해 국소마취하 좌 측 위눈꺼풀 쌍꺼풀선 절개를 통해 종괴 부분 절제 및 조직 생검을 시행하였다. 눈꺼풀올림근널힘줄 앞에 일반적인 눈 꺼풀 지방보다 더 노랗고 경계가 뚜렷하며 단단한 지방 덩 이가 관찰되었다. 이 지방 덩이는 피막으로 싸여 있지는 않 았으며, 안와사이막과의 유착은 없었으나 눈꺼풀올림근과 단단히 붙어있는 양상이었다(Fig. 2A). 내측과 중심부에서 각각 절제하여 조직병리검사를 시행하였다. 조직병리검사 상 섬유격벽으로 나뉘어진 지방 소엽들이 증식된 모습이 관찰되었으며 지방종으로 진단되었다(Fig. 2B). 수술 후 5 개월까지 경과 관찰이 이루어졌고 재발은 없었다.

\section{고 찰}

지방종은 중간엽 조직 기원 종양 중 가장 흔한 종양이다. 몸통, 머리, 목 등 정상적으로 지방이 위치하는 어느 신체 부위에도 발생할 수 있다. 그러나 지방종은 안구 및 안구부 속조직에서는 매우 드물게 발생한다. 지방종은 일반적으로 서서히 커지며 만져지는 덩이 외에 다른 증상을 일으키지 않는다. ${ }^{1}$ 이전에 보고된 안구 및 안구부속조직 지방종에 대 해 살펴보면 외안부에서는 안구결막(bulbar conjunctiva)에 발생한 다형성지방종(pleomorphic lipoma), ${ }^{2,3}$ 각막에 발생 한 지방종이 보고된 바 있다. 전체 안와종양 중 지방종이 차지하는 비율은 약 $0.6 \%$ 에 그치는 것으로 알려져 있다. ${ }^{5}$ 눈꺼풀에서 발생한 단순 지방종의 보고 사례는 매우 드물 다. Thyparampil et $\mathrm{al}^{6}$ 은 15 년간 지속된 좌측 눈꺼풀처짐과
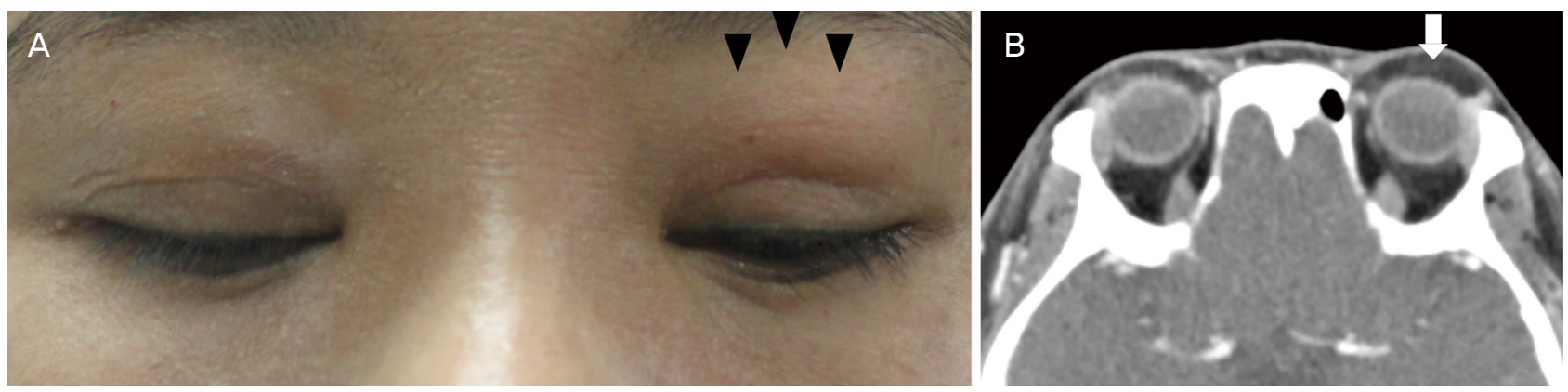

Figure 1. Clinical photograph and orbit computed tomography scan with enhancement image of the patient at initial presentation. (A) Bulging of left upper eyelid was noted on downgaze (arrowheads). Soft tissue like masses were palpable. (B) Hypodense diffuse mass was seen at fat layer of left upper eyelid (arrow) on axial scan of orbit computed tomography.
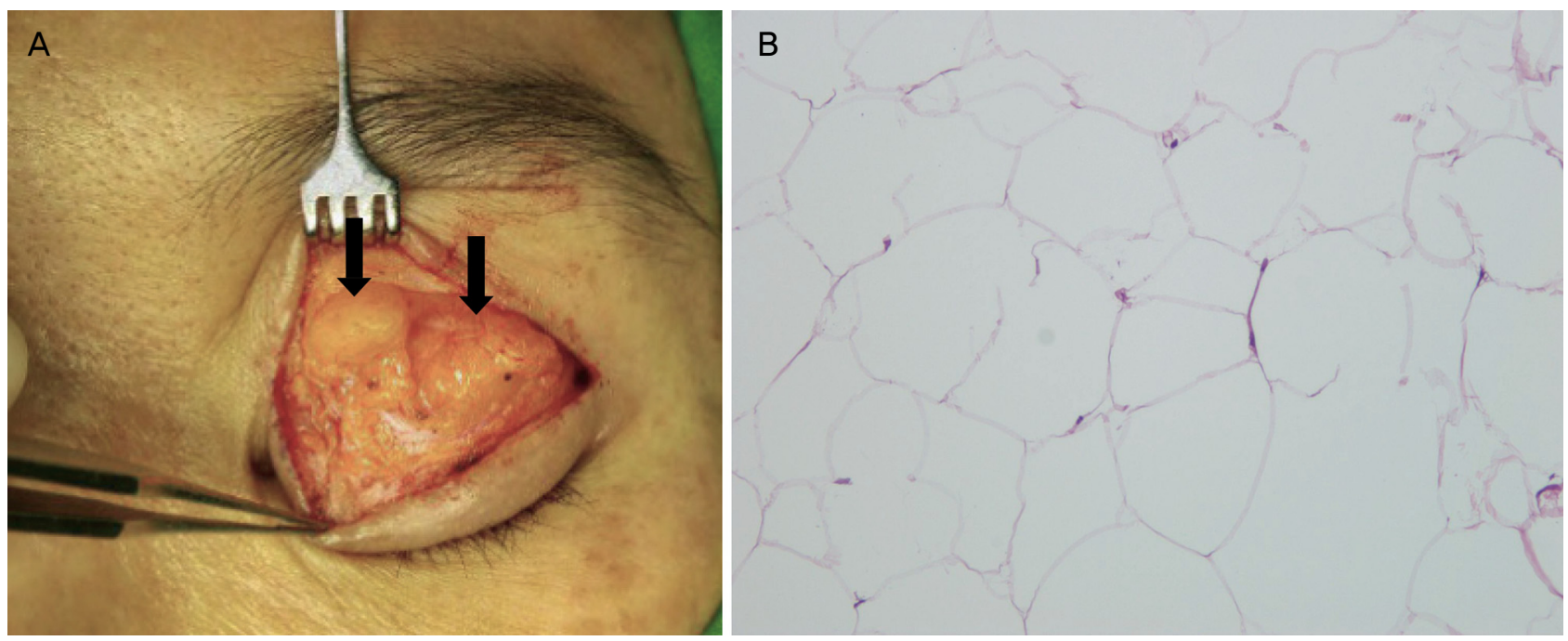

Figure 2. Clinical photograph and histopathology of left upper eyelid lipoma. (A) Yellowish masses (black arrows) were observed at postseptal plane. Masses were firmly stuck to levator aponeurosis. (B) Histopathology showed mature adipocytes consistent with lipoma (hematoxylin and eosin stain $\times 200$ ). 
만져지는 종괴를 주소로 내원한 61세 남자 환자에서 눈꺼 풀올림근널힘줄 앞에 위치한 지방종을 진단하여 보고한 바 있으며, Oliphant et $\mathrm{al}^{7}$ 은 1년 전에 발생한 좌측 눈꺼풀처짐 으로 내원한 61 세 여자 환자에서 단단한 연부조직 질감의 눈꺼풀피부 밑 종괴를 발견하고 절제 생검하여 지방종을 진단한 바 있다. 또한 Maeng et $\mathrm{al}^{8}$ 은 우측 위눈꺼풀부종을 주소로 내원한 57세 여자 환자에서 발생한 안와사이막앞 지방종을 보고하였다. 양성 눈꺼풀종양의 발생 빈도에 대 해 국내에서 발표된 논문들을 살펴보면 지방종의 빈도를 Jang et $\mathrm{al}^{9}$ 은 192 명 중 1 명 $(0.5 \%)$, Kim and Chung ${ }^{10}$ 은 58 명 중 1명 $(1.7 \%)$ 이라고 보고하여 드문 질환임을 확인할 수 있 었다. 반면 Lee and $\mathrm{Lee}^{11}$ 는 64 명 중 3 명 $(4.7 \%)$ 의 빈도를 보고하였는데, 모두 어린이에서 발생하였다고 하였고, 발생 위치 혹은 성상이 기술되어 있지 않아 본 증례와 같은 널힘 줄안와지방에 발생한 종양인지 명확하지 않았다.

기존에 보고된 눈꺼풀지방종 증례들을 살펴보면 일반적 임상양상은 서서히 진행하는 눈꺼풀처짐, 눈꺼풀부종, 점점 커지는 만져지는 종괴 등이었으며, 통증, 발적, 피부 변화 등 염증 연관 증상은 없는 특징을 보였다. ${ }^{5-7,12}$ 안와 CT에서 는 공통적으로 -20 to -200 Hounsfield Units 저음영이며, 조영증강이 되지 않는 지방의 특징을 보여주고 자기공명영 상검사에서는 $\mathrm{T} 1$ 강조영상 및 $\mathrm{T} 2$ 강조영상에서 고신호를 나타낸다. 종괴에 따라서는 경계가 명확히 그려지기도 한 다. 본 증례에서는 종괴의 증상 기간이 2 주로 다른 증례들 에 비해 짧은 경향을 보였으나, 염증 증상 및 징후가 없는, 경도의 눈꺼풀처짐을 동반한 만져지는 종괴로 발현하였으 며, 지방종에 부합하는 안와 CT 소견을 나타내었다.

널힘줄안와지방층에 미만성 종괴가 있는 경우 여러 다른 질환들과의 감별이 필요하다. 특히 지방육아종(lipogranuloma) 을 감별해야 하는데, 환자 병력상 자가지방주입 등의 미용 시술을 받았는지 등에 대한 병력 청취가 필수적이다. 지방 육아종은 안와사이막앞 혹은 눈꺼풀올림근널힘줄 앞의 비 교적 단단하고 매끈한 종괴로 발현하게 된다는 점에서 눈 꺼풀지방종과 비슷하나, 경도 혹은 중등도의 염증 소견을 동반하는 경우가 빈번하며, 경구 스테로이드 및 스테로이 드 주입술에 반응을 잘 한다는 특징이 있다. ${ }^{13,14}$ 안와 CT 검사에서 조영증강이 되며, 조직병리검사상 이물로 인한 육아종성 변화와 만성 염증세포가 넓게 정상 세포에 침착 되어 있고, 지방 세포가 괴사 및 섬유화되어 있다는 점이 감별점이다. ${ }^{13}$ 눈꺼풀에 발생한 림프종 또한 감별이 필요하 다. 특히 안구부속조직 림프종은 저등급 비호지킨 림프종 인 점막관련림프조직종양이 가장 흔한데, 천천히 자라고 주변조직에 침윤이 적어 지방종과 같은 양성종양과의 감별 이 임상적으로 어려울 수 있다. ${ }^{15}$ 안구부속조직 림프종은
자기공명영상에서는 $\mathrm{T} 1, \mathrm{~T} 2$ 강조영상에서 외안근과 비슷 한 음영을 보이고 중등도 조영증강을 보이는 특징이 있으 며, 조직학적 검사에서 단클론성의 비정형 림프구가 미만 성으로 침윤되어 있는 특징을 보인다. ${ }^{16}$ 갑상샘눈병증에 의 한 지방 증대와도 감별이 필요할 수 있다. 갑상샘호르몬검 사와 갑상샘호르몬수용체 자극항체검사, 눈꺼풀후퇴, 눈꺼 풀내림지체 등의 임상적 특징이 여부가 감별진단에 도움이 된다.

본 증례는 쌍꺼풀선을 이용한 종괴의 절제 및 조직병리 검사를 하여 진단과 동시에 치료를 시행하였다. 수술 중 종 괴는 눈꺼풀올림근널힘줄과 단단히 유착되어 있어서, 박리 후 절제가 가능하였는데, 주변조직과의 유착은 이전의 눈 꺼풀지방종 증례 보고에서도 관찰된 바 있다. Thyparampil et $\mathrm{al}^{6}$ 이 보고한 안와사이막 뒤에 위치한 눈꺼풀지방종은 뒷쪽으로 결막 및 눈꺼풀올림근널힘줄과 유착을 보였다고 기술하였으며, 이로 인해 눈꺼풀올림근의 안쪽 뿔(medial horn)이 잘 관찰되지 않았다고 하였다. Maeng et $\mathrm{al}^{8}$ 이 보고 한 안와사이막 앞 눈꺼풀지방종도 눈둘레근, 안와사이막, 눈꺼풀올림근널힘줄의 앞면에 유착되어 있었다고 하였다. 조직병리학적으로 방추세포나 육종세포 없이 성숙한 다수 의 지방세포와 섬유격벽으로 이루어진 특징을 보인다. ${ }^{5}$

결론적으로 눈꺼풀지방종은 흔히 발생하지 않지만 통증 없이 눈꺼풀피부 밑에 미만성으로 종양이 발생한 경우 감 별진단으로 고려하여야 한다. 눈꺼풀올림근널힘줄과 유착 된 형태로 주변 안와조직으로부터 수술적 절제를 통해 제 거하고 조직 생검으로 진단하며 제거 후 재발은 보고되지 않았다. 점진적으로 커지는 눈꺼풀 덩이가 있을 때 감별진 단으로 눈꺼풀 지방종을 고려해야 할 것이다.

\section{REFERENCES}

1) El-Monem MH, Gaafar AH, Magdy EA. Lipomas of the head and neck: presentation variability and diagnostic work-up. J Laryngol Otol 2006;120:47-55.

2) Li E, Silbert J, Sinard J. Pleomorphic lipoma of the bulbar conjunctiva. BMJ Case Rep 2018;11:e226548.

3) Kiaei D, Molinaro R. A negative thyretain TSI bioassay result does not exclude the possibility of the presence of TSI. Horm Metab Res 2020;52:124-5.

4) Subudhi P, Khan Z, Patro S, et al. An unusual case of corneal lipoma. Indian J Ophthalmol 2018;66:455-6.

5) Shah NB, Chang WY, White VA, et al. Orbital lipoma: 2 cases and review of literature. Ophthalmic Plast Reconstr Surg 2007;23:202-5.

6) Thyparampil P, Diwan AH, Diaz-Marchan P, et al. Eyelid lipomas: a case report and review of the literature. Orbit 2012;31:319-20.

7) Oliphant H, Rajak S, Selva D. Simple lipoma of the eyelid: a rare entity. Clin Exp Ophthalmol 2017;45:412-3.

8) Maeng MM, Godfrey KJ, Kazim M. Preseptal upper eyelid lipoma. 
Ophthalmic Plast Reconstr Surg 2019;35:e2-3.

9) Jang SM, Lee H, Baek SH. Clinical characteristics of benign eyelid tumors. J Korean Ophthalmol Soc 2016;57:174-80.

10) Kim KH, Chung WS. Classification and therapeutic effect of benign and malignant eyelid tumors. J Korean Ophthalmol Soc 1997;38:703-9.

11) Lee TS, Lee JJ. Analysis of classification and incidence of eyelid and orbital tumors. J Korean Ophthalmol Soc 1997;38:1700-5.

12) Ali SF, Farber M, Meyer DR. Fibrolipoma of the orbit. Ophthalmic Plast Reconstr Surg 2013;29:e79-81.

13) Park JY, Kim N. Periorbital lipogranuloma after facial autologous fat injection and its treatment outcomes. Korean J Ophthalmol 2016;30:10-6.

14) Sa HS, Woo KI, Suh YL, Kim YD. Periorbital lipogranuloma: a previously unknown complication of autologous fat injections for facial augmentation. Br J Ophthalmol 2011;95:1259-63.

15) Yoon JS, Ma KT, Kim SJ, et al. Prognosis for patients in a Korean population with ocular adnexal lymphoproliferative lesions. Ophthalmic Plast Reconstr Surg 2007;23:94-9.

16) Svendsen FH, Heegaard S. Lymphoma of the eyelid. Surv Ophthalmol 2017;62:312-31.

\section{$=$ 국문초록 $=$}

\section{위눈꺼풀 지방종}

목적: 드문 종양인 좌안 위눈꺼풀에 발생한 지방종을 경험하였기에 이를 보고하고자 한다.

증례요약: 41 세 여자 환자가 2달 전에 발생한 위눈꺼풀 종괴를 주소로 내원하였다. 좌안 위눈꺼풀 널힘줄안와지방으로 추정되는 부위 에 단단한 미만성의 종괴가 만져졌고, 염증성 변화는 없었다. 국소마취하에 부분절제생검을 시행하였으며, 눈꺼풀 정상 지방 조직보다 노랗고 단단한 지방덩이가 관찰되었다. 조직병리검사에서 성숙 지방세포의 증식이 관찰되었으며, 지방종으로 진단되었다. 결론: 몸통 및 팔다리에 흔하게 발생하는 지방종이 눈꺼풀에서도 발생 가능하다. 따라서 눈꺼풀에 미만성 종괴가 있을 때 지방종을 감별진단으로 고려하여야 한다. 외과적 부분 절제 및 병리검사를 통해 진단과 함께 치료를 시행할 수 있다.

〈대한안과학회지 2021;62(7):989-992〉 